\title{
The Relationship between Social Gender and the World of Values in Higher Education
}

VERONIKA BOCSI ${ }^{1}$

$\approx$ The differences between male and female students in the field of education can be studied from several points of view. The aim of the present study ${ }^{2}$ is to approach the issues of mobility closely connected to the educational institution, institutional existence and school, using the filter of value sociology, thus bringing us closer to the different school attitudes and behaviours of the two genders, focusing on higher education. In our analysis, we used the 'Campus-lét' Research database ${ }^{3}$ (2010) of more that 2,000 students $(\mathrm{N}=2,384)$. In the course of completing questionnaires, students responded to the Rokeach Value Survey, which includes 18 terminal and 18 instrumental values evaluated on a five-grade scale. The techniques used were value averages and ranking, factor analysis and analysis of variance. We identified three factors with the use of terminal values (humanist-integrated, seeking happiness in individuals, hedonistic-egoistic) and four with the use of instrumental values (philanthropic, rational, open minded-creative, bureaucratic), with the factor scores indicating a significant relation to gender in five cases.

Keywords: gender differences, Rokeach Value Survey, students, values

1 University of Debrecen, Faculty of Child and Adult Education, Hungary bocsiveron@gmail.com

2 The study was financed by a research project entitled Higher Education for Social Cohesion Cooperative Research and Development in a Cross-Border area (HURO/o901/253/2.2.2.).

3 Campus-lét Research Project. OTKA number: K81858, leader: Prof. Ildikó Szabó. 


\section{Razmerje med družbenim spolom in svetom vrednot $\mathrm{v}$ visokem šolstvu}

VERONIKA BoCSI

$\propto$ Na področju izobraževanja lahko razlike med fanti in dekleti proučujemo z različnih vidikov. Namen raziskave je bil proučiti povezanost mobilnosti v tesni povezavi z izobraževalno institucijo, obstojem institucije in s šolo, ob tem pa uporabiti filter sociologije vrednot, da bi tako podrobneje predstavili razlike med spoloma glede odnosa in vedenja v šoli s poudarkom na visokem šolstvu. $\mathrm{V}$ raziskavo je bilo vključenih več kot dva tisoč študentov $(\mathrm{N}=2.384)$ iz raziskovalne baze »Campus-lét « v letu 2010. V raziskavi je bil uporabljen vprašalnik »Rokeach Value Survey«, ki je sestavljen iz 18 terminalnih in 18 instrumentalnih vrednot, ki so jih študentje ocenjevali na petstopenjski lestvici. Analiza izsledkov vključuje povprečne vrednosti in rangiranje, faktorsko analizo in analizo variance. $Z$ uporabo terminalnih vrednot smo identificirali tri faktorje (humanistično-vključevalni, iskanje sreče pri posameznikih, hedonistično-egoistični), štiri pa z uporabo instrumentalnih vrednot (človekoljubni, racionalni, odprtoustvarjalni, birokratski); izsledki faktorske analize so pokazali statistično pomembno povezanost s spolom $\mathrm{v}$ petih primerih.

Ključne besede: razlike med spoloma, Rekeach Value Survey, študentje, vrednote 


\section{The relation between social gender and the world of values}

As the very first step of our theoretical argumentation, we can assert that the two spheres, the category of social gender and the world of values, are closely connected, and that the logic of this connection is quite unambiguous. One common characteristic of the conceptual definition of values is their being embedded in circumstances, while the other is an emphasis on integration into and adaptation to society, which shifts both the community and the individual towards the final status considered to be desired. Both are based on collective experience and can be interpreted as a certain kind of common agreement (Rokeach, 1973; Schwartz \& Bilsky, 1990). Thus, specific cultures and subcultures, operating as complex systems and bearing groups' interests in mind, establish the frameworks of human behaviour, and thereby also the category of social gender. As they control the process of socialisation and establish its methods and content, both social gender and values represent well regulated and highly efficiency transmission mechanisms. The male and female roles formed by communities in traditional societies can be different, but they are also similar in the sense that they closely fit into the space defined as a common set of values, norms, rules of behaviour and cultural content, while their rules and sanctions are of a collective quality. Rendering the individual construction impossible is not only confined to the field of experiencing social gender; we face a similar phenomenon in connection with, for instance, religion and other intellectual and behavioural constructions. This typical characteristic of communities can be realised as a completely adequate reaction provoked by the interest of the group's survival. Such a train of thought is closely connected to the approach that emphasises the role of biological factors in the construction of values (Csányi, 1994; Hankiss, 1977). In the case of traditional societies, usefulness, making a sacrifice and balancing advantages and disadvantages are not primarily interpreted on the level of the individual due to the collectivist features of communities; therefore, as a source of these advantages and disadvantages, the category of social gender (like many other categories and deeds) occurs more frequently as a problem where individuals are already interpreted as units of analysis by the value system of the community. This makes the objective judgement of (more) traditional gender role interpretation rather complicated from the perspective of a more individualistic value system.

According to Hofstede and Hofstede (2005), we face four fundamental problematic areas, to which different cultures may give different answers: the relation to social inequalities, the relation between the individual and the 
group, the concept of masculinity-femininity, and the way people cope with insecurity. Before outlining Hofstede's typology, we must emphasise that male and female roles in their traditional forms are principally of a complementary nature, not only establishing separate activities and rituals, but also different thinking patterns for the two genders. Opinions differ as to how many common elements there are in these systems (Mead, 1949), whether the systems include the advantage of either gender, and if so why (while approaching the issue with a collectivist logic, this certainly cannot be considered as a relevant question). In the course of his study, which approached the world of values through the world of organisations and the concept of organisational culture, and which is considered to be one of the most wide-ranging international comparative studies in the field of values, Hofstede did not look for differences between men and women. When comparing national cultures, he attempted to draw fault lines, with one of these axes being drawn between self confidence-competitive spirit and care-fostering relationships-preserving the natural environment. When he wanted to interpret the axis, he encountered the fact that the different attitudes can be explained mostly with the aid of gender; therefore, the two poles were named masculine and feminine. Within the world of organisations-workplaces, this involved the following relation to aims-values for the two genders: it shifted men towards high salary, recognition, promotion and challenges, and women towards good work relationships, cooperation, a pleasant environment and security. According to national characterology, Hungarian society has strongly feminine characteristics, while Slovakia, Japan or Austria, for instance, prove to be strongly masculine countries based on Hofstede's examination. The largest distances between the value order of men and women can be found in masculine countries, while in such countries female roles also increasingly include challenges, taking risk and career plans.

Among international studies, we can find several analyses that deal with the different value preferences of men and women. This aspect of values has been examined with the most important value tests, such as the test by Rokeach, Schwartz and Hofstede. Since these tests use diverse methods, the results will also be different. Naturally, the tests have similar elements: belonging to other people, sensitivity, benevolence, universalism, and the sphere of transcendence are more important to women, while logic, openness to change, power, stimulation and a comfortable life are the territory of men. However, these differences are not invariant: the extent of diversity is different in almost every country, and there are countries where some generally feminine values are important to men, such as security in Israel (Sholan, Florenthal, Rose, \&Kropp, 1998). On the basis of Schwartz and Rubel-Lifshitz (2009), we can say that diversity is 
stronger in those countries where equality is more characteristic of the relationship between men and women. In the cited analyses by Sholan et al., the authors point out that the importance of values is different for men and women because women tend to rate them higher.

If we survey the mainstream of Hungarian value sociological research, we can conclude that, in drawing fault lines in the world of values, most analyses concentrate on sociocultural differences (school qualification, occupational categories) or comparison between age groups, rather than the study of differences according to gender. There are, of course, examinations where gender distribution is used, even if their number is not considerable. The transformation and characteristics of the value system of Hungarian society have long been provided by measurement results of the Rokeach Value Survey; in the course of its analysis, relevant research results can be found in several cases. In the case of women, Füstös and Tibori (1995) emphasise increased sociability, while Füstös (1995) observes significant differences in the field of values connected to religion and politics. Comparing the Hungarian results to the value structure of the United States of America, he concludes that gender differences prove to be more significant in Hungary. Surveying child-rearing principles on a national sample, Szabados (1995) concluded that, in percentage terms, fewer women select the values of fantasy, management skills, determination, love of work and independence. In his analysis, he made a distinction between external and internal values (the aim of external values is to help the individual to be accepted by the environment, while the aim of internal values is to create individual balance and individual results), concluding that men preferred internal values and women external values. Jancsák's value sociological analysis of students taking part in teacher training in Szeged and Debrecen (2011) indicates that female students tend towards the direction of postmodern and universal values, while male students tend towards traditional and material values.

Value systems and the constructions of social genders also influence institutional behaviour and attitudes towards it. This can be concluded from the research results of educational sociology, even if in most cases the results of specific measurements and studies are not embedded in value sociology's framing of the problem. Gender differences affect a number of segments of life situations and indicators related to school: it is sufficient to consider the results of surveys connected to student performance in different subjects, behaviour, stereotypes, expectations, motivation or the teacher-student relationship. In the course of studies of school performance according to subjects, we find that, in the first years of education, female students produce higher values even in those fields that should, according to our previous expectations, demonstrate the dominance 
of male students (e.g., maths). Considering school performance in the past few decades, we find that female students are also more successful at secondary level, and in the research of higher education the so-called male disadvantage hypothesis may be formulated in Hungary (Fényes, 2010). In connection with differences in performance, we should note that, in the opinion of most researchers, findings do not really show different indicators and levels of performance, merely different usage and direction of abilities. It is quite certain, however, that these results cannot be analysed completely independent of the worlds of values hidden behind individual behaviours and the terminal and instrumental values of individuals. Different attitudes towards school may also colour conduct and performance at school, because school can be interpreted as a field for adaptation or an institution whose aims and rules are extensively distant from our own rules, resulting in non-conforming behaviour (Willis, 1977). ${ }^{4}$ We could also point out that school appears to be a kind of instrument in the recruitment of certain layers of society, with the help of which desired positions or a scientific career can be realised (female students' advantage in higher education in the area of, for example, academic indicators is no longer evident following the first semester; moreover, fewer female students plan or have already undertaken publications, fewer take part in OTDK (National Scientific Students' Associations), and fewer plan to take part in a doctoral programme (Fényes, 2010)).

\section{Brief description of the analysis and research results}

In the course of our analysis, we used the database of more that 2,000 students $(\mathrm{N}=2,384)$ established by 'Campus-lét' Research in 2010. Inclusion in the sample was not by random selection; the focus of the database was weighted to the variables of gender and faculty. 'Campus-lét' Research was based on a sample of full-time students studying at the University of Debrecen. The university has the highest student numbers among the institutions of Hungary, and, with its 15 faculties, covers a considerable part of the structure of higher education. Although, in terms of its catchment area, it can be regarded as a regional institution, as a large proportion of its students come from the Northern

4 According to Karikó (2005), the fundamental logic and process of rearing-education is conformist; it is therefore not at all irrelevant how a particular group within society is related to the values of conformity, or, in the case of an already existing demand for conformity, whether it is traced back to school or beyond school. In Schwartz's (2003) two-dimensional value model, tradition and security are connected to the sphere of conformity, while stimulation and independence are on the opposite pole. If we consider Karikós findings to be true, this latter model may show which values most probably clash with the process of school education-rearing. Thus, from the point of view of educational sociology, the pole towards which the behaviour and thinking required by the social genders gravitate is not irrelevant. 
Great Plain region, the catchment area of the institution also covers Hungarian minorities living in Romania and the Ukraine. It should be noted that the relatively unfavourable economic indices and social characteristics of the region are also reflected in the sociodemographic situation of the students: among them there is a high proportion of students whose parents do not have a degree (in the case of fathers this proportion is $75.6 \%$, while in the case of the mothers it is $64.5 \%)$. Compared to highly prestigious Hungarian institutions, the proportion of students originating from rural areas can also be considered high (30\% of the students come from villages or farms), and certain university faculties and majors operate as channels for becoming a first-generation intellectual. Thus, the impact of all of these factors on value systems must be taken into consideration in our analysis. Students' value preferences were surveyed with the Rokeach Value Survey's range of values consisting of 36 items, 18 instrumental values and 18 terminal values, with students evaluating the importance of each item on a five-grade scale. ${ }^{5}$ Although this method differs from the usual application of the Rokeach Value Test, we hope that the results obtained bear sufficient relevance. In the course of our analysis, we first used the ranking and averages of the values and then separated factors on both terminal and on instrumental values. Finally, with the aid of variance analysis, we examined which factor would be more characteristic in the case of which gender. Before completing the statistics, we formulated the hypothesis that, although in Hungarian society the university population can be regarded for certain reasons as a group in which categories of social genders are close to each other, differences can still be grasped in the following dimensions:

- in female students' value preferences, values connected to conformity, adaptation and sociability are positioned higher;

- rational and materialistic items are closer to the mentality of male students;

- differences can be grasped in the ranking orders, in the averages and in the factors created.

Being familiar with the results of the Rokeach Value Survey, we can, on the one hand, state that students' value preferences harmonise with the

5 In the questionnaire, students had to indicate how important the listed values are in their lives. In the course of classification, they used a five-grade scale, where one indicated the lowest value and five indicated the highest value. The Rokeach Value Survey contains the following terminal and instrumental values: a comfortable life, a world at peace, happiness, wisdom, family security, inner harmony, equality, a sense of accomplishment, an exciting life, national security, true friendship, mature love, pleasure, self-respect, freedom, a world of beauty, social recognition, salvation (terminal values), imaginative, courageous, broad-minded, obedient, intelligent, selfcontrolled, responsible, capable, cheerful, logical, forgiving, independent, helpful, honest, loving, clean, ambitious, polite (instrumental values). 
Hungarian results and trends obtained in similar studies (e.g., the last position of salvation in the rank order, while at the top of the list there are values connected to happiness and family), but the criteria of being a university student and the endowments of the students' generation also result in certain shifts. This is reflected in how values connected to work, material needs, discipline, close adaptation to society and a helping attitude (helpful, obedient) are ranked lower, while the higher rank achieved by a world at peace and national security in national surveys can also most probably be explained by the effects of age group (Füstös \& Szakolczai, 1999). Not surprisingly, mature love and true friendship, which are among postmaterial values and in the case of adults are ranked in the middle, hold higher positions in the present sample. On the one hand, the higher ranking of values that can be connected to hedonism is in harmony with the trend of youth surveys (Bauer \& Szabó, 2005), but it can also be related to Inglehart's scarcity hypothesis (Inglehart, 1997) due to the special qualities of the student lifestyle. The higher scale values of wisdom, capable and logical must be accounted for by the fact that the respondents were university students, with particular objectives in life, and by the mentality associated with a future intellectual lifestyle, as well as by the sociocultural background of the respondents, which differs from that of the average Hungarian youth. The rank order values of the student sample and the data of subsamples according to genders are shown in Table 1 . The diagram shows that male students positioned the items of freedom, intelligent, logical, courageous, capable, wisdom, ambitious, disciplined (self-controlled) ${ }^{6}$ and a comfortable (prosperous) life higher, while female students did the same with the variables of inner harmony, clean, a world at peace, loving, national security, helpful, social recognition, independent and equality. Thus the picture sketched indicates that the value system of female students is more pacifist, more static, and that they consider the value judgement of the outside world to be more important (social recognition), with more inclusion of the values of helping other people, whereas the world concept of male students is more rational and materialistic. In interpreting the differences in the rank order, the only result in the female students' subsample that is difficult to explain is the higher position of the item of independent. In this case, it might be the independence of a future female graduate, an independent way of life, and providing self-support in a crisis that position the value of independence higher in this subsample. It is important to note that, based on the rank orders, we could not trace differences among values connected to hedonism.

6 The value of disciplined is interpreted by the expression 'self-controlled' in the questionnaire, which may approach traditional male gender roles. 
Table 1. The rank order of Rokeach Value Survey values in the student sample and in the subsamples of the male and female students ${ }^{7}$

\begin{tabular}{|c|c|c|c|c|c|}
\hline \multicolumn{2}{|l|}{ Student sample } & \multicolumn{2}{|l|}{ Male students } & \multicolumn{2}{|l|}{ Female students } \\
\hline happiness & 4.89 & happiness & 4.81 & happiness & 4.93 \\
\hline family security & 4.86 & family security & 4.77 & family security & 4.90 \\
\hline mature love & 4.80 & mature love & 4.66 & mature love & 4.86 \\
\hline inner harmony & 4.76 & true friendship & 4.66 & inner harmony & 4.85 \\
\hline true friendship & 4.74 & honest & 4.66 & true friendship & 4.77 \\
\hline honest & 4.73 & freedom & 4.61 & honest & 4.77 \\
\hline clean & 4.68 & intelligent & 4.60 & clean & 4.74 \\
\hline intelligent & 4.65 & inner harmony & 4.58 & a world at peace & 4.70 \\
\hline responsible & 4.63 & pleasure & 4.57 & responsible & 4.67 \\
\hline freedom & 4.63 & clean & 4.57 & intelligent & 4.67 \\
\hline pleasure & 4.62 & responsible & 4.56 & pleasure & 4.65 \\
\hline cheerful & 4.60 & cheerful & 4.50 & cheerful & 4.65 \\
\hline a world at peace & 4.57 & self-respect & 4.49 & freedom & 4.64 \\
\hline self-respect & 4.57 & logical & 4.49 & self-respect & 4.61 \\
\hline loving & 4.53 & courageous & 4.48 & loving & 4.61 \\
\hline polite & 4.50 & capable & 4.44 & polite & 4.55 \\
\hline an exciting life & 4.50 & an exciting life & 4.43 & an exciting life & 4.54 \\
\hline national security & 4.46 & polite & 4.42 & national security & 4.52 \\
\hline $\begin{array}{l}\text { a sense of } \\
\text { accomplishment }\end{array}$ & 4.46 & wisdom & 4.38 & $\begin{array}{l}\text { a sense of } \\
\text { accomplishment }\end{array}$ & 4.50 \\
\hline courageous & 4.44 & $\begin{array}{l}\text { a sense of } \\
\text { accomplishment }\end{array}$ & 4.37 & helpful & 4.46 \\
\hline capable & 4.44 & loving & 4.36 & social recognition & 4.45 \\
\hline wisdom & 4.42 & national security & 4.34 & independent & 4.45 \\
\hline logical & 4.41 & ambitious & 4.33 & wisdom & 4.44 \\
\hline independent & 4.40 & a world at peace & 4.32 & capable & 4.44 \\
\hline social recognition & 4.38 & self-controlled & 4.32 & courageous & 4.42 \\
\hline helpful & 4.38 & independent & 4.30 & ambitious & 4.37 \\
\hline ambitious & 4.36 & social recognition & 4.24 & logical & 4.36 \\
\hline self-controlled & 4.31 & helpful & 4.22 & equality & 4.34 \\
\hline forgiving & 4.23 & forgiving & 4.10 & self-controlled & 4.31 \\
\hline equality & 4.21 & a comfortable life & 3.99 & forgiving & 4.30 \\
\hline broad-minded & 4.05 & obedient & 3.95 & broad-minded & 4.13 \\
\hline obedient & 4.02 & equality & 3.94 & a world of beauty & 4.11 \\
\hline a world of beauty & 4.02 & broad-minded & 3.89 & obedient & 4.06 \\
\hline a comfortable life & 3.97 & a world of beauty & 3.83 & a comfortable life & 3.96 \\
\hline imaginative & 3.75 & imaginative & 3.79 & imaginative & 3.73 \\
\hline salvation & 3.21 & salvation & 3.09 & salvation & 3.27 \\
\hline
\end{tabular}

7 Values with a difference of at least three positions are highlighted in the table. Values positioned higher are in bold type, while values positioned lower are in bold and italics. 
Examining the scale value averages of the two subsamples, we can observe that female students show a higher commitment to values (Table 2). It is worth emphasising that the advantage of male students is only evident in those dimensions of instrumental values that are related to creativity or rationality, and in the case of terminal values only in connection with material goods. At the same time, the distances seem to be much smaller (in every case their value is below 0.1). We witness the greatest differences between genders in the case of equality (0.4) and a world at peace (0.38), but there are seven more items showing a difference of 0.2 or more (a world of beauty, inner harmony, loving, broadminded, helpful, mature love, forgiving). The scale value averages confirm that the female students' way of thinking is more open to the world and more armed with the intention to help.

Table 2. The average scale values of male and female students based on the Rokeach Value Survey ${ }^{8}$

\begin{tabular}{|l|c|c|}
\hline Terminal values & Male students & Female students \\
\hline a comfortable life & 3.99 & 3.96 \\
\hline a world at peace & 4.32 & 4.70 \\
\hline happiness & 4.81 & 4.93 \\
\hline wisdom & 4.38 & 4.44 \\
\hline family security & 4.77 & 4.90 \\
\hline inner harmony & 4.58 & 4.85 \\
\hline equality & 3.94 & 4.34 \\
\hline a sense of accomplishment & 4.37 & 4.50 \\
\hline an exciting life & 4.43 & 4.54 \\
\hline national security & 4.34 & 4.52 \\
\hline true friendship & 4.66 & 4.77 \\
\hline mature love & 4.66 & 4.86 \\
\hline pleasure & 4.57 & 4.65 \\
\hline self-respect & 4.49 & 4.61 \\
\hline freedom & 4.61 & 4.64 \\
\hline a world of beauty & 3.83 & 4.11 \\
\hline social recognition & 4.24 & 4.45 \\
\hline salvation & 3.09 & 3.27 \\
\hline
\end{tabular}

Continued on the next page

8 In the tables, values showing the five greatest differences, both in the case of terminal and instrumental values, are highlighted in bold type. 


\begin{tabular}{|l|c|c|}
\hline Instrumental values & Male students & Female students \\
\hline imaginative & 3.79 & 3.73 \\
\hline courageous & 4.48 & 4.42 \\
\hline broad-minded & 3.89 & 4.13 \\
\hline obedient & 3.95 & 4.06 \\
\hline intelligent & 4.60 & 4.67 \\
\hline self-controlled & 4.32 & 4.31 \\
\hline responsible & 4.56 & 4.67 \\
\hline capable & 4.44 & 4.44 \\
\hline cheerful & 4.50 & 4.65 \\
\hline logical & 4.49 & 4.36 \\
\hline forgiving & 4.10 & 4.30 \\
\hline independent & 4.30 & 4.45 \\
\hline helpful & 4.22 & 4.46 \\
\hline honest & 4.66 & 4.77 \\
\hline loving & 4.36 & 4.61 \\
\hline clean & 4.57 & 4.74 \\
\hline ambitious & 4.33 & 4.37 \\
\hline polite & 4.42 & 4.55 \\
\hline
\end{tabular}

In the last phase of our analysis, we undertook to model both the terminal and the instrumental values with the aid of factor analysis (Table 3 ). ${ }^{9}$ With regard to terminal values, three factors could be grasped: humanist-integrated, seeking happiness in individuals and hedonistic-egoist factors. Only the first category requires explanation: it involves an arrangement of values whereby thinking in a community (national security, equality) is combined with humanist values (wisdom, inner harmony, sense of accomplishment). In the case of instrumental values, we could separate a philanthropic factor (forgiving, helpful, loving, honest), a rational-careerist factor (capable, ambitious, logical, independent), an open-minded/creative factor (courageous-responsible, broad-minded, imaginative) and a bureaucrat factor (self-controlled, obedient). Our last step was to examine the case of the specific subsamples, and, with the aid of variance analysis, determine which factor their value structures are shifted towards.

9 We rotated the factors with varimax method and used maximum likelihood estimation. When making the models, we kept in mind that by variables the information explained should not fall below one unit. The information content preserved was $37 \%$ with terminal values and $46 \%$ in the case of instrumental values. We could achieve the fitting factor structure by keeping 13-13 values. 
Table 3. Factors of terminal and instrumental values on the basis of the Rokeach Value Survey

\begin{tabular}{|l|c|c|c|}
\hline $\begin{array}{l}\text { Factors of } \\
\text { terminal values }\end{array}$ & Humanist-integrated & $\begin{array}{c}\text { Seeking happiness } \\
\text { in individuals }\end{array}$ & Hedonistic-egoist \\
\hline a world at peace & 0.549 & & \\
\hline happiness & & 0.666 & \\
\hline wisdom & 0.474 & & \\
\hline inner harmony & 0.493 & & \\
\hline equality & 0.571 & & \\
\hline $\begin{array}{l}\text { a sense of accom- } \\
\text { plishment }\end{array}$ & 0.567 & & 0.433 \\
\hline an exciting life & & & \\
\hline national security & 0.479 & & \\
\hline true friendship & & 0.411 & 0.542 \\
\hline mature love & & 0.548 & 0.534 \\
\hline pleasure & & & 0.603 \\
\hline self-respect & & & \\
\hline freedom & & & \\
\hline
\end{tabular}

\begin{tabular}{|l|l|l|c|c|}
\hline $\begin{array}{l}\text { Factors of } \\
\text { instrumental values }\end{array}$ & Philanthropic & Rational & $\begin{array}{c}\text { Open-minded/ } \\
\text { creative }\end{array}$ & Bureaucrat \\
\hline courageous & & & 0.524 & \\
\hline self-controlled & & & & 0.654 \\
\hline capable & & 0.674 & & \\
\hline logical & & 0.553 & & \\
\hline forgiving & 0.567 & & & \\
\hline helpful & 0.638 & & & \\
\hline honest & 0.459 & & & \\
\hline loving & 0.677 & & & \\
\hline ambitious & & 0.460 & & \\
\hline broad-minded & & & 0.499 & \\
\hline obedient & & & & \\
\hline independent & & 0.491 & & \\
\hline imaginative & & & 0.543 & \\
\hline intelligent & & 0.469 & & \\
\hline cheerful & 0.484 & & & \\
\hline
\end{tabular}

The examination of variance analysis by factors produced a total of four significant relations in the case of the two genders (ANOVA test, sig.: 0.05). No difference arose in the category of hedonistic-individualist, confirming our assumption that the dividing lines drawn on the basis of hedonism in society are not to be drawn between men and women, but rather along the borders of 
the layers of society or age group. Nor was any difference evident in the case of open-minded/creative and bureaucrat factors. The former case might be explained by the fact that the item of broad-minded, which was more characteristic of female students, occupied this factor, while in the latter category similar can be said of the inclusion of disciplined (self-controlled) as an instrumental value. However, a significant relation was found in the case of humanist-integrated, seeking happiness in individuals, philanthropic and rational factors (Table 4). The rational factor, which is much more related to having career plans (ambitious), as well as being in agreement with the logic and operating principle of scientific life (capable, intelligent, logical), was much more characteristic of the value system of male students. Female students can be characterised by different aims in life (the factor of seeking happiness in individuals), a different image of man (integrated-humanist), and a relation to a different world (philanthropic).

Table 4. Significant relations between certain factors and the variable of gender

\begin{tabular}{|l|c|c|c|c|}
\hline & Humanist-integrated & $\begin{array}{c}\text { Seeking happiness } \\
\text { in individuals }\end{array}$ & Philanthropic & Rational \\
\hline male students & -0.25 & -0.22 & -0.25 & 0.06 \\
\hline female students & 0.95 & 0.99 & 0.92 & -0.03 \\
\hline Sig. & 0.000 & 0.000 & 0.000 & 0.015 \\
\hline
\end{tabular}

\section{Summary}

In our analysis, we were seeking an answer to the question as to what difference can be observed between male and female students in the world of values in a population where the thinking structures and behavioural norms of social genders are expected to appear less characteristically than in the average for Hungarian society, and in a medium where male and female students' behavioural, performance-related and positional conditions and regulations are much closer to each other. Having completed the analyses, we can state that significant and well-interpreted differences can be found between the value preferences of the two genders, which, on the one hand, confirm our hypotheses, and, on the other hand, can also be interpreted in the world of education. Our expectations were that significant differences would be found between male and female students - gender differences evident in mentality due to the characteristics of students' sphere of life - in the world of higher education, a 
world that would otherwise be capable of reducing differences in value preferences. It is important to emphasise that our expectations were also related to those fields of values that should operate universally (e.g., rationality) based on the logic of higher education. Our hypotheses have been proved in the course of our analysis, as the world of values of female students is more embedded in society and the community, and can be described with philanthropic intentions in this direction, while, with regard to their aims in life, personal relationships are more highly appreciated. The higher position of social recognition in the rank order refers to the fact that female students tend to evaluate themselves based on the opinion of the community. Male students, however, have a more rational, career-centred, materialistic image of the world, and their judgement about themselves and their aims in life are much more independent of the community. It should be noted that these differences were evident in the case of all three techniques (averages, ranking orders, factor analysis) used for surveying the values. If, on the one hand, we project this onto the school's world of life, we discover an explanation of female students' more conformist behaviour derived from values that tends towards taking school norms more into consideration. Concerning female students' adaptation to school, however, we might raise the question as to whether they really undergo interiorisation of the aims of school, or whether their attitude can be explained merely by a desire to integrate into institutional existence. The teacher stereotypes mentioned in the theoretical chapter of our study may also confirm this behaviour in the case of the two genders. Our results obtained in the field of values might also be relevant with regard to university faculties and the phenomenon of certain professions becoming a female preserve, as, on the one hand, the results may account for the choice of a major that is helping, social and focused on people, while, on the other hand, they may also be related to less ambitious academic career plans during the university years. We hope that in the near future our research results may complete the theoretical frameworks of studies related to higher education addressing the issues of certain majors becoming a female preserve, gender differences with regard to achievement in higher education, labour market attitudes and differences in the career plans of male and female students, while also harmonising with the gender-centred study of mobility. In conclusion, we must make it absolutely clear that value structures are systems that change slowly, but are not static: a study conducted a few decades earlier would most probably have determined greater distances between the two genders (while it is important to emphasise that social genders' approaching each other is not a completely unambiguous and one-way process: one only has to think of American society after the Second World War). The characteristics 
of behavioural rules, aims in life, norms and values formed by social genders are also embedded in the conditions of the environment, economic changes and the characteristics of educational institutions. Nevertheless, the process is two-way: the change of values is not only the end result, but, following Weber's (2001) logic, might well be the starting point of phenomena affecting the whole of society. The question is what attitudes towards education will be formed in the different layers of society by the value systems conveyed by changing gender roles, what reactions will be formed as a response to them in the world of education, and how the two genders' career prospects and their opportunities to enter the different levels and stages of education will be affected by structural changes in education, such as the changes in higher education.

\section{References}

Bauer, B., \& Szabó, A. (2005). Ifjúság 2004. Gyorsjelentés. Budapest: Mobilitás Ifjúsági Iroda. Csányi, V. (1994). Viselkedés, gondolkodás, társadalom: etológiai megközelités. Budapest: Akadémiai Press.

Fényes, H. (2010). A nemi sajátosságok különbségének vizsgálata az oktatásban. A nők hátrányainak felszámolódása? Debrecen: Debrecen University Press.

Füstös, L. (1995). A társadalom értékrendjének strukturális mérőeszköze az összehasonlitó vizsgálatokban. Budapest: MTA Szociológiai Kutatóintézet.

Füstös, L., \& Szakolczai, Á. (1999). Kontinuitás és diszkontinuitás az értékpreferenciákban (1977 1998). Szociológiai Szemle, 9(3), 54-73.

Füstös, L., \& Tibori, T. (1995). Önértékelés és társadalmi helyzet strukturális kapcsolódásai értéktípusonként. Budapest: MTA Szociológiai Kutatóintézet.

Hankiss, E. (1977). Érték és társadalom. Tanulmányok az értékszociológia köréből. Budapest:

Magvető Press.

Hofstede, G., \& Hofstede, G. J. (2005). Cultures and Organizations: Software of the Mind. Revised and expanded 2nd Edition. New York: McGraw-Hill.

Inglehart, R. (1997). Modernization and Postmodernization: Cultural, Economic and Political Changes in 43 Countries. Princeton: Princeton University Press.

Jancsák, Cs. (2011). Tanárjelöltek értékvilága. In T. Kozma, \& I. Perjés (Eds.), Új kutatások a neveléstudományokban 2010: Törekvések és lehetőségek a 21. század elején (pp. 145-159). Budapest:

ELTE Eötvös Press.

Karikó, S. (2005). Konformitás és nevelés. Budapest: Okker Press.

Keller, T. (2008). A modernizációs folyamat hatása az értékrendre. In S. K. Nagy, \& A. Orbán (Eds.), Értékek és normák interdiszciplináris megközelítésben (pp. 387-418). Budapest: Gondolat Press. Mead, M. (1949). Male and Female: A Study of the Sexes in a Changing World. New York: Morrow Quill. 
Rokeach, M. (1973). The nature of human values. New York: Free Press.

Schwartz, Sh. (2003). Univerzáliák az értékek tartalmában és struktúrájában: elméleti előrelépések és empirikus próbák húsz országban. In Sz. I. Váriné (Ed.), Értékek az életben és a retorikában. Budapest: Akadémiai Press.

Schwartz, S. H., \& Bilsky, W. (1990). Toward a theory of the universal psychological structure of human values. Journal of Personality and Social Psychology, 53, 550-562.

Schwartz, S. H., \& Rubel-Lifschitz, T. (2009). Cross-national variation in the size of sex differences in values: Effects of gender equality. Journal of Personality and Social Psychology, 97(1), 171-185.

Sholan, A., Florenthal, B., Rose, M. G., \& Kropp, F. (1998). Differences in value importance - the impact of age and gender in the israeli population. Advances in Consumer Research, 25, 468-474. Szabados, T. (1995). Gyermeknevelési elvek a magyar társadalomban. Budapest: MTA Szociológiai Intézete.

Weber, M. (2001). The protestant ethic and the spirit of capitalism. London: Routledge Press. Willis, P. (1977). Learning to Labor: How Working Class Kids Get Working Class Jobs. New York: Columbia University Press.

\section{Biographical note}

VERONIKA Bocsi was born in 1978 (Eger, Hungary). She attended the University of Debrecen (Hungary) and obtained degrees in History and Sociology. From 2003 to 2009 she was a student in Education Studies Program of the Doctoral School of Humanities (University of Debrecen). Veronika Bocsi defended her thesis in 2009 and she started to work at the Faculty of Child and Adult Education as an assistant professor in the same year. Her main fields of interest are the world of higher education, the sociology of lifestyle and the sociology of values. 